\title{
Pengaruh Optis Kontak Belakang terhadap Parameter Optis Lapisan a-Si:H
}

\author{
Ismail $^{*}$ dan Eddy Yahya \\ Jurusan Fisika-FMIPA, Institut Teknologi Sepuluh Nopember \\ Kampus ITS Sukolilo, Surabaya 61111
}

\begin{abstract}
Intisari
Lapisan a-Si:H dideposisikan dalam substrat corning gelas eagle XG di PECVD dengan parameter deposisi: temperatur substrat $270^{\circ} \mathrm{C}$, tekanan 530 mTorr, laju aliran silan $\mathrm{Si} H_{4} 20 \mathrm{sccm}$, aliran hidrogen $70 \mathrm{sccm}$ dalam waktu 30 menit, diperoleh ketebalan lapisan sekitar 437,2 nm. Kontak belakang Al, Ag, Al/Ag dideposit dalam evaporator MVSystem dengan tekanan vakum 5,0.10 ${ }^{-6}$ torr, sekitar (5 - 10) detik. Plot grafik menggunakan pengukuran data transmisi dari sampel dengan monokromator pada panjang gelombang 400-750 nm pada kisaran $10 \mathrm{~nm}$ dalam temperatur kamar $28,5^{\circ} \mathrm{C}$. Sampel diukur dengan mengkondisikan sudut datang dan sudut bias mendekati normal $\left(\theta_{i} \approx \theta_{r} \approx 0\right)$. Peningkatan faktor optis $m$ a-Si:H/Al=1,563 - 1,635, $m$ a-Si:H/Ag $=1,584-1,616$, dan $m$ a-Si:H/Al/Ag = 2,932 - 3,016. Pengaruh kontak belakang $f\left(R_{B}\right)$ a-Si:H/Al = 1,1531 - 1,1581, $f\left(R_{B}\right)$ a-Si:H/Ag $=1,1552-1,1603, f\left(R_{B}\right)$ a-Si:H/Al/Ag $=1,1573-1,1625$. Pengumpulan muatan model optis $Q E$ a-Si:H/Al = 0,8361 - 0,8723, $Q E$ a-Si:H/Ag = 0,8362 - 0,8739, $Q E$ a-Si:H/Al/Ag = 0,8387 0,8755 .
\end{abstract}

KATA KUNCI: pengaruh kontak belakang, faktor peningkatan optis, lapisan a-Si:H.

\section{LATAR BELAKANG}

Lapisan aktif silikon terhidrogenasi a-Si: H, belakangan ini menjadi yang paling intensif dipelajari dalam semikonduktor. Sel surya berbahan silikon amorf relatif murah dibandingkan dengan sel surya silikon kristal, namun memiliki efisensi yang rendah. Berbagai metode digunakan untuk meningkatkan efisiensinya, salah satunya dengan mengoptimalkan kontak belakang sebagai reflektor cahaya. Lapisan $\mathrm{p}$ dan $\mathrm{n}$ juga terjadi generasi hole-elektron seperti pada lapisan a-Si:H, namun pada lapisan $\mathrm{p}$ dan $\mathrm{n}$ proses tersebut relatif kecil sehingga tidak memberikan pengaruh pada pengumpulan muatan dan bisa diabaikan. Sel surya a-Si:H p-i-n mempunyai efisiensi yang rendah dan relatif lebih murah bila dibandingkan dengan sel surya c-Si. Struktur sel surya silikon amorf a-Si:H pi-n bergantung oleh absorbsi cahaya oleh lapisan a-Si:H yang merupakan lapisan aktif.

Pada lapisan a-Si:H, foton cahaya yang terabsorbsi akan digunakan untuk mengeksitasi elektron dari pita valensi menuju pita konduksi. Kontak belakang yang didepositkan berfungsi secara optis sebagai reflektor yang akan merefleksikan cahaya, sehingga cahaya yang terabsorbsi oleh lapisan aktif a-Si:H meningkat. Kontak belakang dengan $\mathrm{Al}$ yang pada umumnya digunakan akan terjadi pertumbuhan alumina $\mathrm{Al}_{2} \mathrm{O}_{3}$ secara alami untuk selang waktu tertentu sehingga menurunkan efisiensi kerja sel [1]. Karakterisasi secara optis untuk mengetahui penggaruh optis $f\left(R_{B}\right)$ dari kontak belakang terhadap penyerapan cahaya oleh lapisan a-Si:H, serta efisiensi pengumpulan muatan secara optis (efisensi quantum $Q E$ ) kontak belakang $\mathrm{Al}, \mathrm{Ag}$, dan $\mathrm{Al}: \mathrm{Ag}$. terhadap fak-

*E-MAIL: ismail@gmail.com

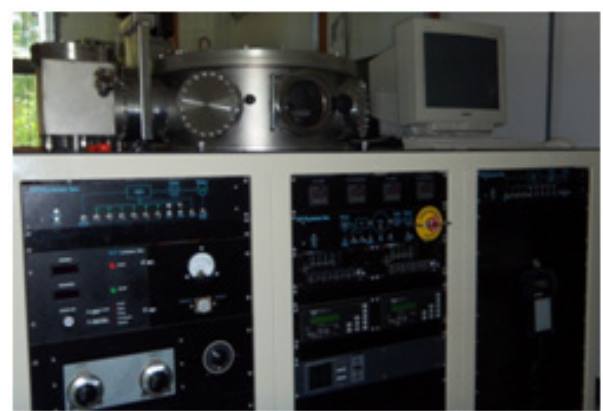

Gambar 1: PECVD Multichamber MVSystem.

tor peningkatan optis m dikarakterisasi dengan menggunakan monokromator dan detektor thorlabs.

\section{EKSPERIMEN}

Lapisan a-Si:H dideposisi pada substrat corning glass eagle XG dengan ukuran $(10 \times 10) \mathrm{cm}^{2}$ ketebalan $1,1 \mathrm{~mm}$, menggunakan PECVD (Plasma Enhanced Chemical Vapour Deposition) pada chamber PL3, dengan parameter deposisi laju silan $20 \mathrm{sccm}$, tekanan $530 \mathrm{mTorr}$, temperatur $270^{\circ} \mathrm{C}$, dan laju hidrogen $70 \mathrm{sccm}$. Sistem PECVD multichamber MVSYSTEM diperlihatkan pada Gambar 1.

Metalisasi adalah pemberian lapisan logam pada bagian belakang lapisan a-Si:H yang berperan sebagai kontak listrik dan reflektor cahaya. Lapisan logam yang dipergunakan adalah aluminium, perak dan aluminium:perak, ditumbuhkan melalui tehnik evaporasi, menggunakan evaporator MVSytem (Gambar 2).

Kontak belakang hasil metalisasi berukuran $(1 \mathrm{x} 1) \mathrm{cm}^{2}$ dan 


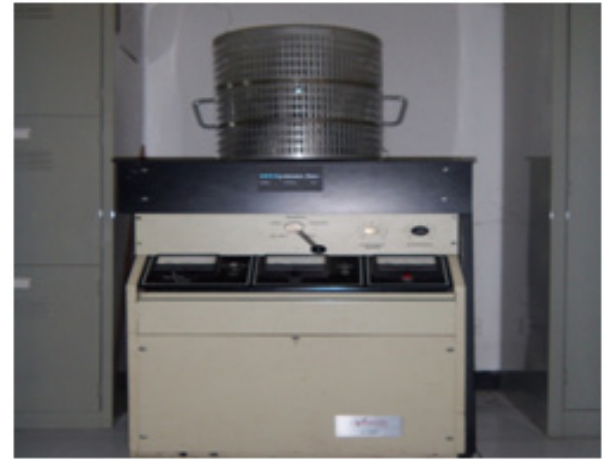

Gambar 2: Evaporator MVSystem.

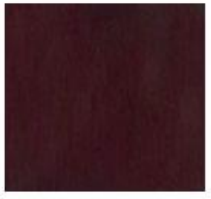

a-Si:H

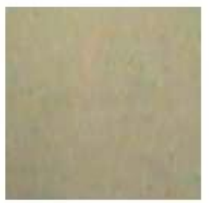

a-Si:H/Ag

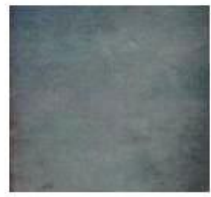

a-Si:H/Al

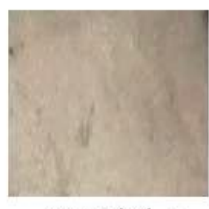

a-Si:H/Al:Ag
Gambar 3: Hasil deposisi dan metaliasai permukaan lapisan a-Si:H

$(0,5 \times 0,5) \mathrm{cm}^{2}$ [2]. Hasil deposisi lapisan a-Si:H di PECVD dan metalisasi di evaporator diperlihatkan pada Gambar 3.

Sampel dikarakterisasi dengan menggunakan sistem monokromator pada panjang gelombang 400-750 nm. Skema karakterisasi dengan seperangkat monokromator terlihat pada Gambar 4. Detektor diletakkan didepan dan belakang sampel yang terhubung dengan layar detektor. Jarak antara sumber cahaya lampu $100 \mathrm{~W}$ dengan objek $9 \mathrm{~cm}$. Intensitas cahaya datang yang melalui monokromator terukur sebagai intensitas cahaya datang $\mathrm{I}_{\circ}$, dan intensitas cahaya sesudah mengenai sampel terukur sebagai intensitas cahaya transmisi $\mathrm{I}_{t}$.

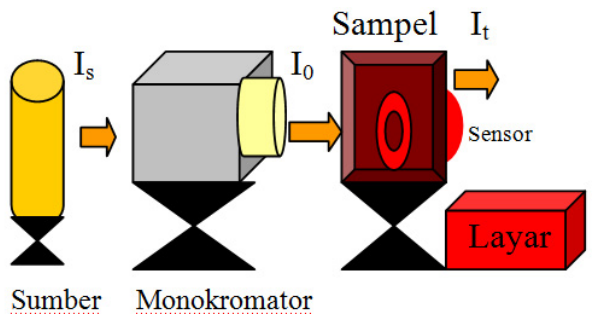

Gambar 4: Pengukuran parameter optis lapisan a-Si:H.

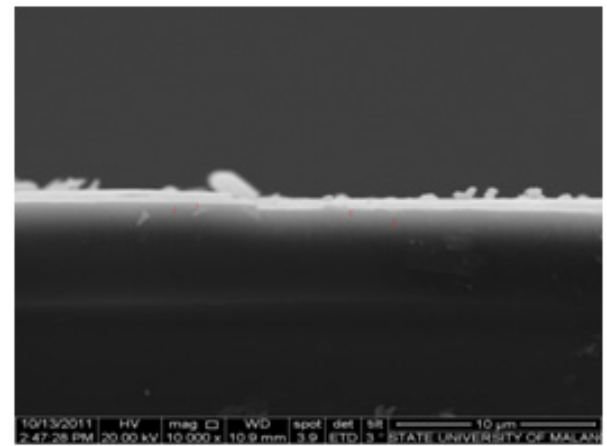

Gambar 5: Penampang silang lapisan Al/Ag, a-Si:H dan Ag dengan SEM.

\section{ANALISIS DAN PEMBAHASAN}

Indeks bias $\mathrm{S}$, dari transmisi corning glass eagle $\mathrm{XG} T_{S}$, diperoleh dari metode swanepoel [3]:

$$
S=\frac{1}{T_{S}}+\sqrt{1-\frac{1}{T_{S}^{2}}}
$$

diperoleh indeks bias berkisar 1,3461 pada panjang gelombang $400 \mathrm{~nm}$ hingga 1,5156 pada panjang gelombang $530 \mathrm{~nm}$, sedangkan indeks bias lapisan a-Si:H dihitung berdasarkan:

$$
n_{i}=N_{i}+\sqrt{N_{i}^{2}-S^{2}}
$$

dengan

$$
N_{i}=2 S\left[\frac{T_{M}-T_{m}}{T_{M} T_{m}}\right]+\frac{S^{2}+1}{2}
$$

dengan $T_{M}, T_{m}$ transmisi maksimum-minimum yang terbaca pada detektor Thorlabs tiap panjang gelombang, diperoleh indeks bias a-Si:H berkisar 3,071 pada panjang gelombang 440 $\mathrm{nm}$ hingga 4,97 pada panjang gelombang $560 \mathrm{~nm}$. Ketebalan lapisan a-Si:H dan kontak belakang diukur dengan menggunakan Scanning Electron Microscope (SEM) [4], seperti yang diperlihatkan Gambar 5. Ketebalan lapisan a-Si:H sekitar 437,2 nm, sedangkan ketebalan lapisan kontak belakang $\mathrm{Al}$ dan Ag 349,7 nm dan metal Al:Ag 612 nm.

Ketebalan lapisan a-Si:H dapat pula dihitung dengan menggunakan [5]:

$$
d=\frac{\lambda_{M} \lambda_{m}}{2\left({ }_{m} \lambda_{M}-\lambda_{m} n_{M}\right)}
$$

dengan d ketebalan lapisan, $\lambda_{M}, \lambda_{m}$ panjang gelombang maksimum, minimum pada $n_{M}, n_{m}$ indeks bias a-Si:H oleh transmisi minimum maksimum. Variasi ketebalan pada daerah panjang gelombang tertentu terlihat pada Tabel I, yang diperoleh ketebalan lapisan a-Si:H sekitar 431,045 nm. Kontak belakang menyebabkan meningkatnya penyerapan cahaya oleh lapisan a-Si:H, seperti yang diperlihatkan Gambar 6 dan 7 . 
TABEL I: Ketebalan lapisan a-Si:H pada variasi panjang gelombang

\begin{tabular}{cc}
\hline \hline$\lambda$ & $\mathrm{d} \mathrm{a}-\mathrm{Si}: \mathrm{H}(\mathrm{nm})$ \\
\hline $510-650$ & $d_{1}=245,61$ \\
$650-750$ & $d_{2}=846,075$ \\
$490-750$ & $d_{3}=201,45$ \\
$\bar{d}$ & $=431,045$ \\
\hline
\end{tabular}

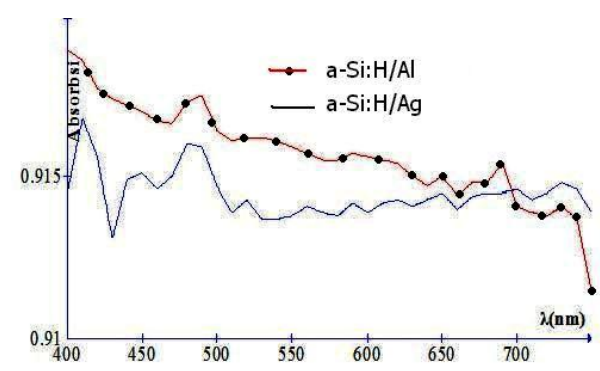

Gambar 6: Penyerapan cahaya oleh lapisan a-Si:H /Al: dan a-Si:H /Ag.

Penyerapan cahaya oleh lapisan a-Si:H dan Al berkisar 0,9131 - 0,9168, kecenderungan stabil setelah panjang gelombang $500 \mathrm{~nm}$, sedangkan penyerapan cahaya oleh lapisan a$\mathrm{Si}: \mathrm{H}$ dan Ag berkisar 0,9114 - 0,9189, yang terus menurun dengan kenaikan panjang gelombang.

Penyerapan cahaya oleh lapisan a-Si:H dan $\mathrm{Al} / \mathrm{Ag}$ berkisar $0,9893-0,99$, terjadi penurunan penyerapan pada panjang gelombang 590 - $610 \mathrm{~nm}$. Energi gap diperoleh dengan menarik linear kurva kelengkungan dari energi tinggi ke energi rendah melalui persamaan [6]:

$$
\sqrt{h \alpha v}=B\left(h \nu-E_{o p}\right)
$$

dan Gambar 8 memperlihatkan $\mathrm{E}_{o p}$ sekitar 1,65 eV.

Cahaya yang berasal dari lapisan a-Si:H sebagian akan diteruskan ke kontak belakang dan sebagian direfleksikan kembali ke lapisan a-Si:H, sehingga pada umumnya cahaya akan menempuh jarak 2 kali dari jarak yang ditempuh cahaya di lapisan a-Si:H tanpa kontak belakang akibat dari faktor peningkatan optis. Peningkatan faktor optis $m$ merupakan jarak

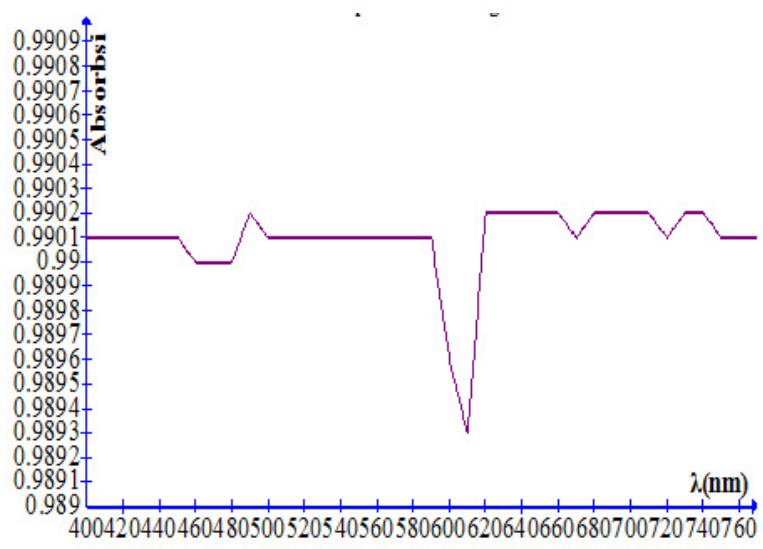

Gambar 7: Penyerapan cahaya oleh lapisan a-Si:H /Al:Ag.

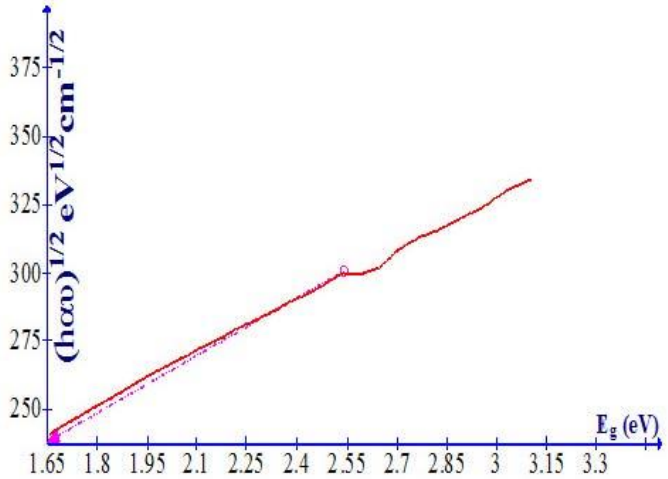

Gambar 8: Diagram bandgap lapisan a-Si:H

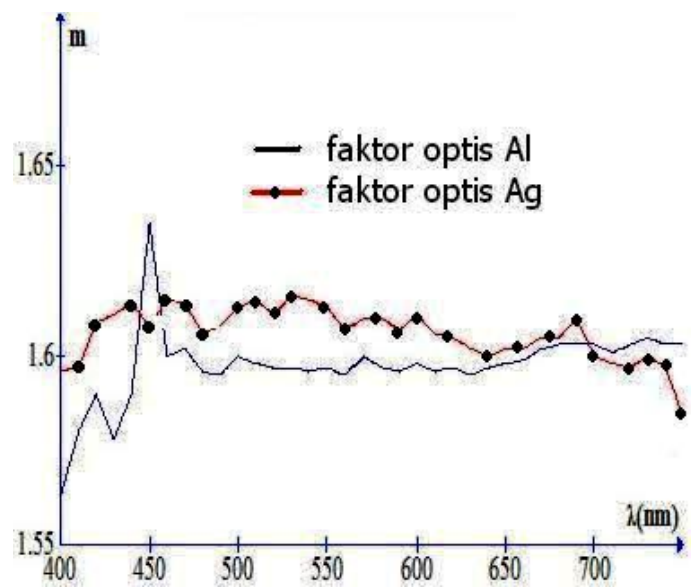

Gambar 9: Peningkatan faktor optis a-Si:H /Al: dan a-Si:H /Ag.

rata-rata yang dilalui tiap panjang gelombang sebelum diserap lapisan a-Si:H [7]. Faktor peningkatan optis ditentukan dari transmisi lapisan a-Si:H dengan kontak belakang T, koefisien absorbsi $\alpha$ dan $\mathrm{x}$ tebal lapisan a-Si:H sesuai persamaan:

$$
-\ln T=m \alpha x
$$

Faktor peningkatan optis oleh lapisan a-Si:H/Al berkisar 1,563 - 1,635, peningkatan faktor optis lapisan a-Si:H oleh $\mathrm{Ag}$ berkisar antara 1,584 - 1,616. Lapisan a-Si:H/Al cenderung menyerap panjang gelombang (450 - 750) nm, sedangkan Lapisan a-Si:H/Ag cenderung menurun pada panjang gelombang (450 - 750) nm seperti yang diperlihatkan pada Gambar 9.

Faktor peningkatan optis oleh lapisan a-Si:H/Al:Ag berkisar antara 2,932 - 3,016, terjadi penurunan penyerapan pada panjang gelombang $(600$ - 610) nm terlihat pada Gambar 10.

Pengaruh kontak belakang pada penyerapan cahaya oleh lapisan a-Si:H dinyatakan dengan persamaan:

$$
f\left(R_{B}\right)=R_{B}\left(1-A_{i}\right)
$$

dengan $A_{i}$ adalah absorbsi lapisan a-Si:H dan $R_{B}$ adalah faktor refleksi antar permukaan lapisan a-Si:H dan kontak belakang yang berkisar antara 0,2-1 yang didapatkan dari struktur kontak belakang sebagai reflektor [8]. Nilai $R_{B}$ kontak 


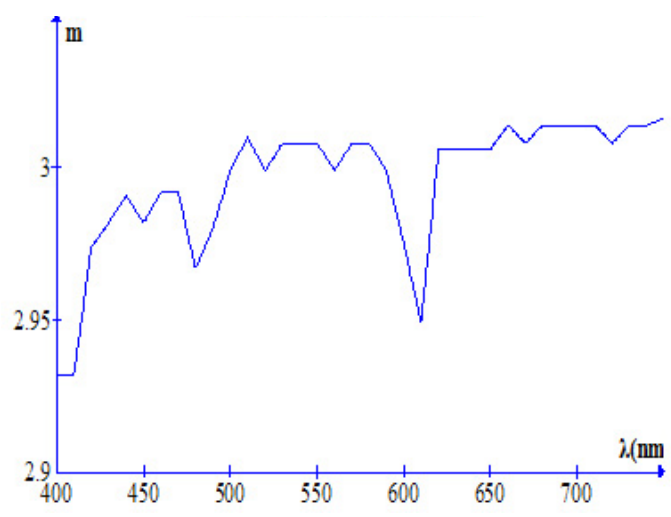

Gambar 10: Peningkatan faktor optis a-Si:H /Al:Ag.

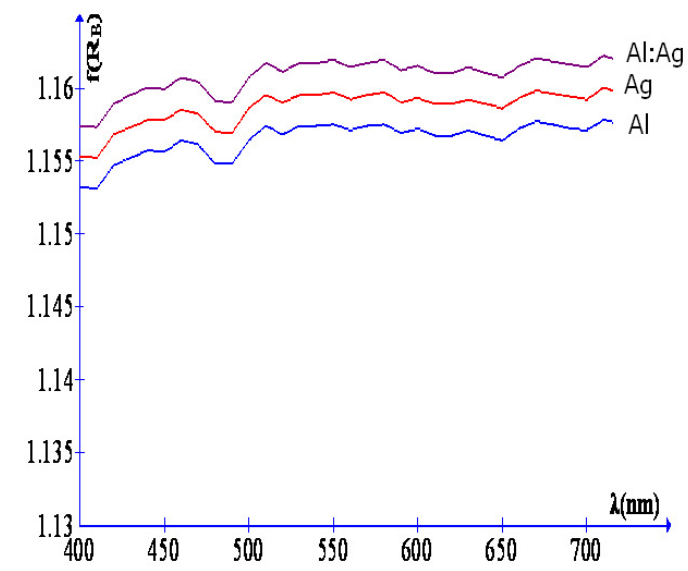

Gambar 11: Pengaruh kontak belakang Al, Ag, Al:Ag.

belakang yang didepositkan pada lapisan a-Si:H adalah $R_{B}$ $\mathrm{Al}=0,73, R_{B} \mathrm{Ag}=0,74$ dan $R_{B} \mathrm{Al}: \mathrm{Ag}=0,75$. Pengaruh optis kontak belakang Al berkisar 1,1531 - 1,1581, pengaruh optis kontak belakang Ag berkisar 1,1552 - 1,1603, seperti yang diperlihatkan pada Gambar 11, sedangkan faktor pengaruh optis kontak belakang Al/Ag berkisar 1,1573 - 1,1625. Pengaruh optis ketiga kontak belakang cenderung stabil setelah panjang gelombang $500 \mathrm{~nm}$.

Meskipun peningkatan faktor optis dengan kontak belakang Al:Ag dua kali lebih besar dibandingkan dengan kontak belakang $\mathrm{Al}$ ataupun $\mathrm{Ag}$, namun pengaruh optisnya tidak berbeda jauh dengan pengaruh optis yang disebabkan oleh kontak belakang $\mathrm{Al}$ ataupun $\mathrm{Ag}$, hal ini didisebabkan cahaya yang direfleksikan oleh sisi belakang metal Al:Ag tidak seluruhnya mencapai lapisan a-Si:H, sebagian akan terserap pada batas logam Al dan Ag, paling tidak lapisan Ag ini akan mencegah tumbuhnya alumina pada $\mathrm{Al}$.

Efisiensi perngumpulan muatan $Q E$ merupakan perbandingan foton yang berinteraksi dengan elektron dan foton yang diserap oleh lapisan a-Si:H, dengan menggunakan model optis, pengumpul muatan ditentukan oleh persamaan:

$$
Q E(\lambda)=T_{t} A_{i}\left[1+f\left(R_{B}\right)\right]
$$

dengan $T_{t}$ transmisi cahaya dari corning glass eagle XG.

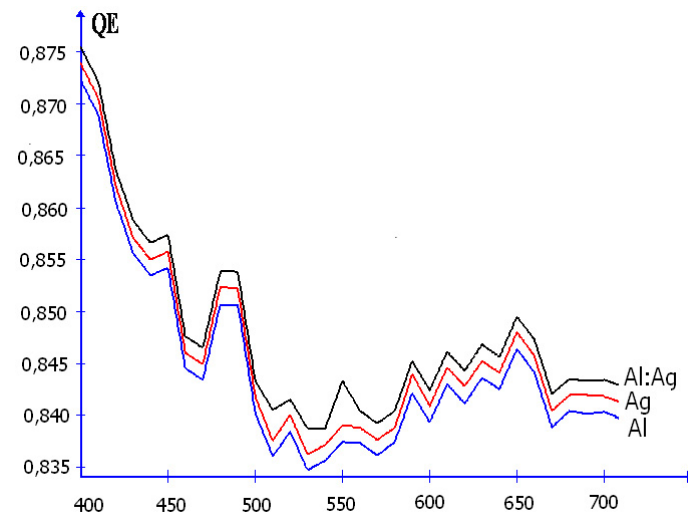

Gambar 12: Pengumpulan muatan kontak belakang Al, Ag, Al:Ag.

Gambar 12 memperlihatkan nilai pengumpulan muatan $Q E$ lapisan a-Si:H pada ketiga kontak belakang. Pengumpul muatan oleh kontak belakang Al berkisar 0,8361 - 0,8723, dengan kontak belakang Ag berkisar 0,8362 - 0,8739, dan kontak belakang Al:Ag berkisar 0,8387 - 0,8755.

Untuk ketiga lapisan metal ( $\mathrm{Al}, \mathrm{Ag}, \mathrm{Al}: \mathrm{Ag})$ terdapat penurunan yang tajam pada panjang gelombang (400 - 540) nm, dan perlahan meningkat pada panjang gelombang (540 - 650) $\mathrm{nm}$, yang kemudian perlahan turun pada panjang gelombang (650 - 750) nm. Nampak terlihat bahwa efisiensi pengumpul muatan pada kontak belakang $\mathrm{Al}$ :Ag relatif lebih besar dibandingkan dengan kontak belakang pada $\mathrm{Al}$ ataupun $\mathrm{Ag}$, walaupun perbedaannya tidak terlalu signifikan.

\section{SIMPULAN}

Pengaruh kontak belakang sebagai faktor peningkatan optis, dengan ditandai meningkatnya penyerapan cahaya oleh lapisan a-Si:H. Faktor peningkatan optis merupakan jarak rata-rata cahaya sebelum diserap oleh lapisan a-Si:H, terjadi karena cahaya terefleksi oleh kontak belakang. Faktor peningkatan optis dengan kontak belakang $\mathrm{Al}$ :Ag sekitar 2,932 3,016 dengan penyerapan cahaya berkisar 0,9893 - 0,99. Pengaruh kontak belakang $\mathrm{Al} / \mathrm{Ag}$ pada penyerapan cahaya oleh lapisan a-Si:H sekitar 1,1573 - 1,1625. Pengumpul muatan pada kontak belakang Al/Ag sekitar 0,8387 - 0,8755. Lapisan metal Ag yang didepositkan pada metal Al sebagai pencegah tumbuhnya alumina pada $\mathrm{Al}$.
[1] J. Bartl, M. Baranek, Measurement of Physical Quantities 4, 31 (2004).
[2] R. Swanepoel, J. Phys. E: Sci. Instrum, 16, 1214 (1983).

[3] N.A. Bakr, et al., PRAMANA-journal of physics Indian 
Academy of Sciences, 76, no.3, March (2011).

[4] C. Hsu, et al., Nano Res, 3, 307 (2010).

[5] N. Pimpabute, et al., Optica Applicata, XLI, no.1, 3 (2011).

[6] B.M. Curtin, Photonic crystal back-reflectors for light management and enhanced absorption in a-Si:H solar cells, Thesis M.Sc, Iowa State University Ames, Iowa, 2009.

[7] K. Takahashi and M. Konagai, Amorphus silicon solar cell (Original Japanese language edition, Shokodo Ltd.,Tokyo, 1986).

[8] A. Luque, and S. Hegedus, Handbook of Photovoltaic Science and Engineering (2nd edition, John Wiley \& Sons, Inc., New York, 2011).

[9] R. Kaplan, and B. Kaplan, Turk J. Phys. TUBITAK, 26, 363 (2000).

[10] B.W. Lewis, Silica Nanosphere Textured Back Reflectors for Increased Absorption in Thin Film Amorphous Silicon Solar Cells, Thesis M.Sc., Iowa State University Ames, Iowa, 2010. 